\title{
OPTIMIZATION OF THE ETHANOL FERMENTATION OF CASSAVA WASTEWATER USING RESPONSE SURFACE METHOD
}

\author{
A. M. UMO, K. C. EGEMBA, E. N. BASSEY AND B. R. ETUK \\ (Received 3, August 2012; Revision Accepted 10, May 2013)
}

\begin{abstract}
This research work focused on the optimisation of the cassava wastewater medium for ethanol fermentation. The main thrust was the investigation of the influence of the glucose concentration, nutrient $\left(\mathrm{NH}_{4} \mathrm{Cl}\right)$ level, and cell concentration on the yield of ethanol from cassava wastewater. Twenty experiments based on rotatable central composite design (CCD) were conducted. The factors affecting the ethanol yield were optimised within the following range of values (15 to 25 ) $\mathrm{g} / \mathrm{l}$ of glucose concentration, (2 to 4) $\mathrm{g} \mathrm{NH}_{4} \mathrm{Cl}$ level and (300 to 400) CFU cell concentration in $100 \mathrm{ml}$ of the substrate using response surface methodology (RSM). The optimum values of these factors- glucose concentration, nutrient level, and cell concentration were found to be $24.991 \mathrm{~g} / \mathrm{l}, 3.991 \mathrm{~g}$ and 399.94 CFU respectively. These gave a yield of $8.69 \% \mathrm{v} / \mathrm{v}$ of ethanol in the broth within the range of the values of the factors that were investigated. Optimising cassava wastewater as the medium for ethanol production would improve the ethanol yield, and thereby reduce the cost of production.
\end{abstract}

KEYWORDS: Ethanol, cassava wastewater, optimization, culture medium, response surface methodology

\section{INTRODUCTION}

Biofuels which are fuels derived from biomass sources are receiving attention globally. These renewable energy sources have the capacity to reduce the dependence on fossil fuels, ensure the availability of clean energy and create employment in rural communities ( Nzelibe \& Okafoagu, 2007; Ranola et al., 2009; Egemba \& Babatunde, 2008). Bioethanol is the principal biofuel used as a substitute to gasoline as transportation fuel, although at the moment it is mainly used in blends with gasoline as E10 and E20 (10 and 20\% ethanol mixed with 90 and $80 \%$ gasoline respectively) (Ibeto et al., 2011).

Bioethanol can be obtained from a variety of feedstocks using sugar, starchy and cellulosic sources, such as sugarcane, whey, cassava, corn, sorghum, cornstalk, straw and woodwaste. A challenge in the use of some of these feedstocks in bioethanol production is the ethical and moral issues that are raised, since they serve as human food sources. Hence the use of feedstocks that do not compete as food, agricultural wastes and wastes from various food processing operations for bioethanol production is receiving special attention (Teerapatr et al., 2004). Cassava wastewater has the potential to be utilized for bioethanol production because of its cellulose, hemi-cellulose and starch contents (Ranola et al.,2009; Taherzadeh \& Karimi, 2008; Teerapatr et al., 2004).

Nigeria is the largest producer of cassava in the world. In 2005, she produced
A. M. Umo, Department of Chemical and Petroleum Engineering, University of Uyo, Uyo, Nigeria
K. C. Egemba, Department of Chemical and Petroleum Engineering, University of Uyo, Uyo, Nigeria
E. N. Bassey, Department of Chemical and Petroleum Engineering, University of Uyo, Uyo, Nigeria
B. R. Etuk, Department of Chemical and Petroleum Engineering, University of Uyo, Uyo, Nigeria 
about $40,000,000$ tonnes of cassava; Brazil produced about $25,000,000$ tonnes while the rest of the world produced about 20,000,000 tonnes of cassava (Kuiper et al., 2007). The use of wastewater from cassava processing for bioethanol production will reduce the environmental menace associated with its disposal, generate wealth and serve as an alternative to the fast depleting fossil fuels ( Teerapatr et al., 2004; Egemba \& Babatunde, 2008).

In the fermentation process of producing ethanol, some factors which affect the yield of ethanol include, sugar concentration, nutrient concentration, cell concentration, reaction time, $\mathrm{pH}$ and temperature of the medium (Manikandan \& Viruthagiri, 2010; Teerapatr et al., 2004; Prescott \& Dunns, 2004). For bioethanol to become economically competitive, these conditions must be optimized to improve the efficiency of the process (DaCosta \& Filho, 2004). This will reduce production cost on account of increased yield of ethanol, reduce waste and also promote energy use efficiency. The foregoing possibilities have heightened the interest in optimizing the ethanol yield from bioethanol processes, and have led to various research efforts in this regard. Some of these efforts have focused on cell immobilization to achieve higher ethanol yield (Amutha \& Gunasekaran, 2001; Alegre et al.,2003). Optimization of the culture medium and the fermentation conditions have also been explored for improving the yield of ethanol fermentation processes (Tsoutsas et al., 1990; Kongkiattikajorn et al., 2007; Ratnam et al., 2005). Improving process performance by the selective removal of ethanol during fermentation is yet another approach that has been reported. This approach is made possible because ethanol fermentation is inhibited by product, therefore simultaneous removal of product during fermentation can promote higher yield (Amenaghawon, 2010).

In recent times, response surface methodology has been combined with factorial design of experiment method to provide efficient ways to optimize bioprocesses, using reduced number of experiments. This approach offers better performance in locating a true optimum than methods which vary one variable at a time. It also has the ability to reveal the interactions that exist between process variables (Mandenius \& Brundin, 2008; Manikandan \& Viruthagiri, 2010; Popa et al., 2007).
This work is focused on the optimization of ethanol production from cassava wastewater fermentation. Thus, it investigates the influence of sugar concentration, nutrient concentration and cell concentration on the yield of ethanol from cassava wastewater. The study applies Response Surface Methodology in the optimization process.

\section{MATERIALS AND METHODS}

\subsection{MATERIALS}

Barium chloride (99\%, Surechem), Sulphuric acid (98\%, Aldrich), Sodium hydroxide (97.5\%, BDH), Ammonium molybdate (99.9\%, Aldrich), Sodium potassium tartrate (99\%, Lab Tech Chemicals), anhydrous Sodium carbonate (99.9\%, Aldrich), Copper sulphate pentahydrate (99\%, Sigma), Sodium hydrogen carbonate (99.5\%, Phillip Harris), Sodium sulphate (99.5\%, M\&B) and lodine solution used for the work were purchased from a laboratory chemical and equipment shop in Uyo, Akwa lbom State. Cassava wastewater was obtained from a local cassava processing factory in Use Offot village, Uyo, Akwa Ibom State.

The yeast cells used were
Sacchromyces cerevisiae
purchased from a chemical shop in Uyo, Akwa Ibom State. The inoculum was prepared by adding $10 \mathrm{~g}$ of baker yeast to $100 \mathrm{ml}$ of $40{ }^{\circ} \mathrm{C}$ distilled water in a beaker. Glucose $(14 \mathrm{~g})$ was added to the inoculum and the yeast was allowed to grow.

Arsenomolybdate Reagent: This was obtained by preparing a solution of $25 \mathrm{~g}$ ammonium molybdate in $450 \mathrm{ml}$ distilled water. Distilled water $(21 \mathrm{ml})$ containing $3 \mathrm{~g}$ disodium hydrogen arsenate heptahydrate was then added with stirring at $37^{\circ} \mathrm{C}$. The solution was stored in a 1 litre glass-stopper brown bottle (Wrolstad et al., 2007).

Low-alkalinity Copper Rreagent: This was obtained by preparing a solution of $12 \mathrm{~g}$ sodium potassium tartrate and $24 \mathrm{~g}$ anhydrous sodium carbonate in $250 \mathrm{ml}$ distilled water. A solution of $4 \mathrm{~g}$ copper sulphate pentahydrate and $16 \mathrm{~g}$ sodium hydrogen carbonate in $200 \mathrm{ml}$ distilled water was added. A solution of $180 \mathrm{~g}$ anhydrous sodium sulphate in $500 \mathrm{ml}$ of boiling distilled water was separately prepared. The two solutions were combined in a volumetric flask and diluted to 1 litre (Wrolstad et al., 2007). 
Design Expert 7 software by Stat-Ease Inc., was used in implementing the optimization strategy. This software is a specialized statistical package for the design of experiments, which offers tools for response surface methods (RSM) with unique evaluation capabilities.

\subsection{EXPERIMENTAL PROCEDURE}

\subsubsection{ACID HYDROLYSIS}

Cassava wastewater (10 L) was measured into a stainless steel pot and $100 \mathrm{ml}$ concentrated $\mathrm{H}_{2} \mathrm{SO}_{4}$ added. The pot was heated in an electric hot plate until the solution formed a gel and began to foam. As hydrolysis proceeded, the colour formed with iodine solution changed from blue black to dark red and then to pale orange. When a pale orange colour was observed, indicating complete hydrolysis, the heating was stopped. The sample was allowed to settle, separating into 3 layers. The liquid layer (middle) was separated by decantation and filtered. The filtrate had a $\mathrm{pH}$ of 2.13. It was neutralized with $600 \mathrm{ml}$ of $2 \mathrm{M} \mathrm{NaOH}$ solution to a $\mathrm{pH}$ of 7.76. The solution was allowed to settle. A soapy colour was observed below and a transparent light brown colour above - the glucose solution was decanted. The supernatant was analyzed for the amount of reducing sugar using the method of Vlyssides et al. (2009).

\subsubsection{FERMENTATION}

The supernatant $(500 \mathrm{ml})$ taken from the acid hydrolysis stage was transferred into rubber containers. The reducing sugar in the containers were inoculated with yeast cell culture in various concentrations and solid ammonium chloride in accordance with the runs in the proposed experimental matrix using 'Design Expert 7' software (Stat-Ease Inc. (2003). The fermentation processes were carried out at a $\mathrm{pH}$ of 7.76 and temperature of $30^{\circ} \mathrm{C}$ for 5 days. The samples were later withdrawn and analyzed for ethanol yield according to the method of Prescott and Dunns, (2004).

\subsection{ANALYTICAL PROCEDURE}

The quantity of reducing sugar in the hydrolysed cassava wastewater was determined by the Nelson-Somogyi method as reported in Wrolstad et al. (2007). The various concentrations of glucose used in the experiments were then obtained by diluting the stock solution accordingly. The concentration of the yeast culture added to the fermentation medium was measured by the McFarland Turbidity Method as described by Scott (2006).

\subsubsection{DETECTION OF REDUCING SUGAR IN HYDROLYZED CASSAVA WASTEWATER}

A blank solution was prepared by adding $1 \mathrm{ml}$ low-alkalinity copper reagent and $2 \mathrm{ml}$ of arsenomolybdate reagent. The spectrophotometer was set at $500 \mathrm{~nm}$, the lamp of the spectrophotometer allowed to warm up and the blank solution was used to zero the instrument. A standard solution of $1 \mathrm{mg} / \mathrm{ml}$ glucose was prepared in distilled water. Aliquots of $0.1 \mathrm{ml}$ to $0.6 \mathrm{ml}$ were pipette to different $10 \mathrm{ml}$ tubes. At this point, all the test tubes contained $0.1 \mathrm{mg}$ to $0.6 \mathrm{mg}$ of glucose to which, $1 \mathrm{ml}$ of lowalkalinity copper reagent was added. The tubes were heated in boiling water for 10 mins; $2 \mathrm{ml}$ of arsenomolybdate reagent added; the volume diluted to $5 \mathrm{ml}$ and allowed to stand for at least 15 mins at room temperature. A blue colour of different thickness was observed after the addition of $2 \mathrm{ml}$ of the arsenomolybdate reagent. The solution was transferred from the test tube to burette and the absorbance measured at $500 \mathrm{~nm}$ (A500). A standard graph of weight $(\mathrm{mg})$ of glucose versus A500 was then constructed (Wrolstad et al., 2007).

\subsubsection{DETERMINATION OF GLUCOSE IN HYDROLYSED CASSAVA WASTEWATER}

The supernatant from the acid hydrolysis stage was pipette into $100 \mathrm{ml}$ flask. Distilled water was added to dilute the sample to $100 \mathrm{ml}$. The sample $(1 \mathrm{ml})$ in the flask was pipette into a test tube and $1 \mathrm{ml}$ of low-alkalinity copper reagent added. The test tube was heated for 10 mins then $2 \mathrm{ml}$ of arsenomolybdate reagent added and the volume diluted to $5 \mathrm{ml}$. After 15 mins, the absorbance was read with the spectrophotometer (as 1.556). The mass of glucose in the test tube $(0.29 \mathrm{mg})$ was obtained by reading mass $(\mathrm{mg})$ from the intercept made by the absorbence in the standard graph. The calculation of the concentration of the glucose in the stock solution after hydrolysis was obtained by applying Equation (1):

Concentration of glucose $=\frac{\text { mass of sample in test tube }}{\text { volume of sample pipette into test tube }} \times$ dilution factor 
A. M. UMO, K. C. EGEMBA, E. N. BASSEY AND B. R. ETUK

\subsubsection{DETERMINATION CONCENTRATION FERMENTATION MEDIUM OF CELL IN THE}

McFarland standard was obtained by preparing a $1 \%$ solution of anhydrous $\mathrm{BaCl}_{2}$ and a $1 \%$ solution of sulphuric acid. The $1 \% \mathrm{BaCl}_{2}$ and $1 \% \mathrm{H}_{2} \mathrm{SO}_{4}$ were mixed in the ratios as given in the McFarland scale and shown in Table 1.
The absorbance of the mixtures were measured and plotted against the corresponding McFarland standard colony forming unit (CFU)/ml to obtain the standard graph. The absorbance of the yeast cell (in slurried form) was measured in a spectrophotometer and the concentration $(\mathrm{CFU} / \mathrm{ml})$ read from the standard graph. (Scott, 2006).

Table 1: Approximate E. coli Concentration on McFarland Scale (Scott, 2006).

\begin{tabular}{|l|l|l|}
\hline McFarland scale & CFU $(\mathbf{x} \mathbf{1 0} / \mathbf{m l})$ & $\mathbf{1} \% \mathbf{B a C l}_{2} / \mathbf{1}_{\mathbf{6}} \mathbf{H}_{\mathbf{2}} \mathbf{S O}(\mathbf{m l})$ \\
\hline 1 & 300 & $0.1 / 9.9$ \\
\hline 2 & 600 & $0.2 / 9.8$ \\
\hline 3 & 900 & $0.3 / 9.7$ \\
\hline 4 & 1200 & $0.4 / 9.6$ \\
\hline 5 & 1500 & $0.5 / 9.5$ \\
\hline 6 & 1800 & $0.6 / 9.4$ \\
\hline 7 & 2100 & $0.7 / 9.3$ \\
\hline 8 & 2400 & $0.8 / 9.2$ \\
\hline 9 & 2700 & $0.9 / 9.1$ \\
\hline 10 & 3000 & $1.0 / 9.0$ \\
\hline
\end{tabular}

\subsubsection{DETERMINATION OF PERCENTAGE ALCOHOL IN THE WORT.}

The wort obtained after fermentation for 5 days was filtered and the final specific gravity (SG) measured with a pycknometer at $20^{\circ} \mathrm{C}$. The refractive index $(\mathrm{RI})$ was also measured with a refractometer at $20{ }^{\circ} \mathrm{C}$. The percentage alcohol by weight in the 20 samples of the experiment were calculated using Declerk's equations (Peter, 2009), as shown in equations (2), (3) and (4).

\section{$=\frac{\text { weight of sample }+ \text { pyknometer }- \text { weight of pyknometer }}{\text { weight of water }}$}

$\mathrm{v} / \mathrm{v} \%=\mathrm{w} / \mathrm{w} \% \times \mathrm{SG} / 0.79$

$\mathrm{w} / \mathrm{w} \%=1018-(277.4 \times \mathrm{SG})+\mathrm{RI}[(937.8 \times \mathrm{RI})-1805]$

\subsection{RESPONSE SURFACE MODEL DEVELOPMENT \\ Optimization of the process parameters} in ethanol fermentation using cassava waste water as medium was studied using response surface method (RSM). The glucose concentration $\left(x_{\mathbf{1}}, \mathrm{g} / \mathrm{l}\right)$, nitrogen level $\left(x_{\mathbf{2}}, \mathrm{g}\right)$ and yeast cell concentration $\left(X_{\mathbf{a}}, \mathrm{CFU}\left(\times 10^{6} / \mathrm{ml}\right)\right)$ were chosen as the independent variables and ethanol concentration $(y, g / l)$ was the response variable.
A full factorial experimental design with 20 experiments was employed.

The variable $x_{i}$ were coded as $X_{i}$ as shown in equation (5) in which $X_{i}$ is the dimensionless value of an independent variable. $x_{i}$ is the real value of the independent variable, $x_{0}$ is the real value of the independent variable at central point (basic) and $\Delta^{x_{i}}$ is the step change of variables $x_{i}$.
$\mathrm{x}_{\mathrm{i}}=\frac{x_{i}-x_{0}}{\Delta x_{i}}$

The response surface model for the fermentation was proposed and implemented using 'DesignExpert 7' software. Based on experimental data, a second order polynomial was therefore developed to predict the response, $Y$ (ethanol concentration, $g / l)$, as shown in equation (6). 
$Y=b_{0}+b_{1} x_{1}+b_{2} x_{2}+b_{3} x_{3}+b_{12} x_{1} x_{2}+b_{2 \mathrm{a}} x_{2} x_{3}+b_{1 \mathrm{a}} x_{1} x_{3}+b_{2 \mathrm{z}} x_{2}^{2}+b_{3 \mathrm{a}} x_{3}^{2}$

Where:

$\mathrm{b}_{0}=$ offset term (intercept),

$b_{1}, b_{2}, b_{3}=$ linear effects (regression coefficients of single factors),

$b_{12}, b_{13}, b_{23}, b_{11}, b_{22}, b_{33}=$ are the interaction effects (regression coefficients of double factors).

\subsection{GOODNESS- OF- FIT}

Analysis of variance (ANOVA) was performed on the quadratic model to ascertain its goodness-of-fit. P-value was used as a tool to check the significance of each coefficient, which also indicates the interactive strength between the respective independent variables, while regression coefficient $\left(R^{2}\right)$ was used to determine the correlation between the model and the experimental data.

\section{RESULTS AND DISCUSION}

The results obtained from this work are presented and discussed under the following subheadings.

\subsection{STANDARD GRAPHS}

The standard graph of the weight of glucose versus absorbance (at $500 \mathrm{~nm}$ ) which was used to determine the glucose concentrations is shown in Figure 1, while Figure 2 is the plot of the cell concentration of yeast against absorbance, from which the cell concentrations were determined. As can be seen from Figures 1 and 2, the coefficient of determination $\left(R^{2}\right)$ values of 0.98 and 0.97 for the plots of the weight of glucose versus absorbance and the cell concentration of yeast against absorbance respectively are very high, suggesting that the glucose concentrations and the cell concentrations can be accurately obtained from the respective plots.

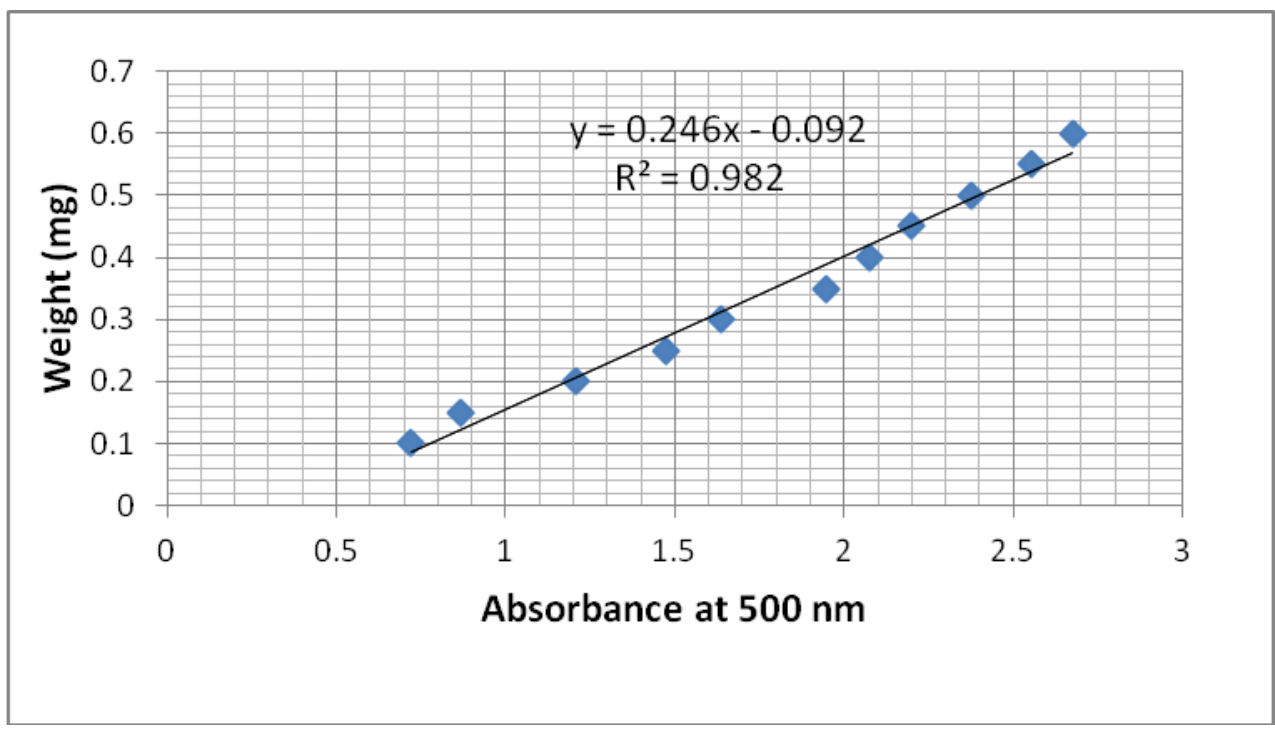

Figure 1: Standard Graph of the Weight of Glucose versus Absorbance 


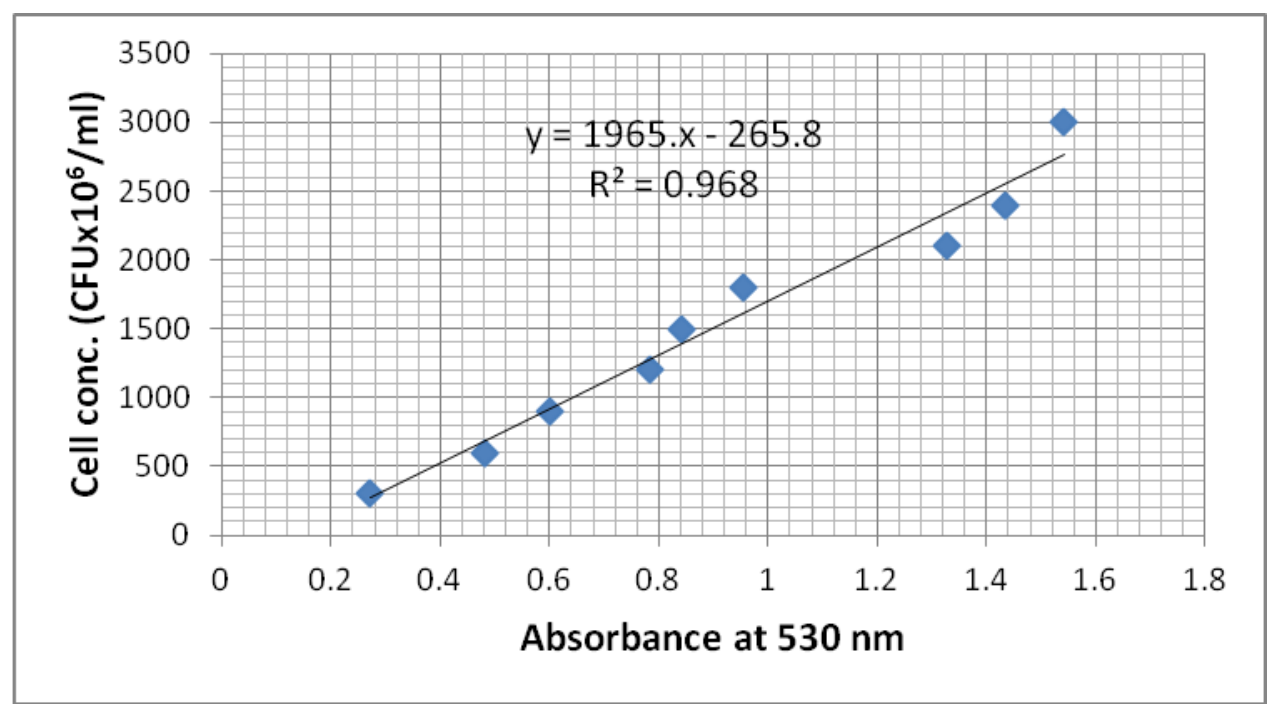

Figure 2: Plot of the Concentration of Yeast Cell against Absorbance

3.2. EXPERIMENTAL DESIGN MATRIX the 'Design Expert 7' software, which shows the FOR THE FERMENTATION range and level of experimental variables The design matrix obtained from using investigated in the study is presented in Table 2.

Table 2: The Experimental Matrix for Rotatable Central Composite Design CCD $\left(2^{3}\right)$ with Observed and Predicted Yields of Ethanol $(Y)$

\begin{tabular}{|l|l|l|l|l|l|l|l|l|}
\hline & \multicolumn{5}{|l|}{ Coded value } & \multicolumn{4}{l|}{ Actual value } & Observed & Predicted \\
\hline Run & $\mathrm{X}_{1}$ & $\mathrm{X}_{2}$ & $\mathrm{X}_{3}$ & $x_{\mathbf{1}}$ & $x_{\mathbf{2}}$ & $x_{\mathbf{3}}$ & $\mathrm{Y}_{\text {obs }}$ & $\mathrm{Y}_{\text {pred }}$ \\
\hline & & & & $\mathrm{g} / \mathrm{l}$ & $\mathrm{g}$ & $\begin{array}{l}\text { CFU } \\
\mathrm{X} 10^{6} / \mathrm{ml}\end{array}$ & $\%$ & \%vol \\
\hline 1 & -1 & -1 & 1 & 15 & 2 & 400 & 3.49 & 3.20 \\
\hline 2 & 1.68 & 0 & 0 & 28.41 & 3 & 350 & 8.68 & 7.69 \\
\hline 3 & 1 & 1 & 1 & 25 & 4 & 400 & 8.13 & 8.70 \\
\hline 4 & -1 & -1 & -1 & 15 & 2 & 300 & 3.28 & 3.24 \\
\hline 5 & 0 & 0 & 0 & 20 & 3 & 350 & 5 & 5.42 \\
\hline 6 & 0 & 0 & 0 & 20 & 3 & 350 & 5.56 & 5.42 \\
\hline 7 & 0 & 0 & -1.681 & 20 & 3 & 265.91 & 5.43 & 4.70 \\
\hline 8 & -1 & 1 & 1 & 15 & 4 & 400 & 4.56 & 4.54 \\
\hline 9 & -1 & 1 & -1 & 15 & 4 & 300 & 3.57 & 3.94 \\
\hline 10 & 0 & -1.68 & 0 & 20 & 1.32 & 350 & 2.08 & 2.12 \\
\hline 11 & 0 & 0 & 1.6817 & 20 & 3 & 434.08 & 6.15 & 6.15 \\
\hline 12 & -1.68 & 0 & 0 & 11.59 & 3 & 350 & 3.29 & 3.55 \\
\hline 13 & 0 & 1.68 & 0 & 20 & 4.68 & 350 & 6.47 & 5.72 \\
\hline 14 & 1 & -1 & -1 & 25 & 2 & 300 & 3.46 & 4.00 \\
\hline 15 & 0 & 0 & 0 & 20 & 3 & 350 & 5.47 & 5.42 \\
\hline 16 & 0 & 0 & 0 & 20 & 3 & 350 & 5.33 & 5.42 \\
\hline
\end{tabular}




\begin{tabular}{|l|l|l|l|l|l|l|l|l|}
\hline 17 & 0 & 0 & 0 & 20 & 3 & 350 & 5.66 & 5.42 \\
\hline 18 & 1 & -1 & 1 & 25 & 2 & 400 & 4.96 & 5.12 \\
\hline 19 & 0 & 0 & 0 & 20 & 3 & 350 & 5.32 & 5.42 \\
\hline 20 & 1 & 1 & -1 & 25 & 4 & 300 & 6.14 & 6.94 \\
\hline
\end{tabular}

Twenty experiments (on basis of rotatable central composite design (CCD)) were carried out with different combinations of variables, which included six centre points. The central point value chosen for experimental design were: glucose concentration (20 g/l), $\mathrm{NH}_{4} \mathrm{Cl}$ level $(3 \mathrm{~g})$ and cell concentration (350 $\left.\mathrm{CFU}\left(\times 10^{6} / \mathrm{ml}\right)\right)$. The developed regression equation is an empirical relationship between the ethanol yield and test variables in coded units; equation (7) was obtained. The increase in the value of a variable with positive coefficient in the model will increase ethanol yield while variable with negative coefficient decreases ethanol yield. It can be observed from the model that glucose concentration has the largest coefficient. This indicates that the glucose concentration has the most significant effect on the ethanol yield followed by the nutrient level and the cell concentration in that order.

$$
\text { Yield }(Y)=5.42+1.23 x_{1}+1.07 x_{2}+0.43 x_{2}+0.56 x_{1} x_{2}+0.29 x_{1} x_{3}+0.16 x_{2} x_{3}+0.072 x_{1}^{2}-0.53 x_{2}^{2}
$$

\subsection{RESPONSE SURFACE QUADRATIC MODEL PREDICTIONS}

The percentage difference between the experimentally observed values and the model predicted values in Table 2, ranged from $0 \%$ (run 11 ) to $15 \%$ (run 14). The percentage difference for ten of the 20 experimental runs (runs 4, 6, 8, $10,11,15,16,17,18$ \&19) were below $5 \%$, while six of the runs showed percentage difference above $10 \%$. The Plot of the experimental ethanol yield versus the model predicted yield (Figure 3.) can be used to assess the quadratic model prediction. The coefficient of determination $\left(R^{2}\right)$ was obtained to be 0.92 . This indicates that the model can predict the process with good accuracy, as only $8 \%$ of the total variations are not explained by the model (Rahman et al., 2007).

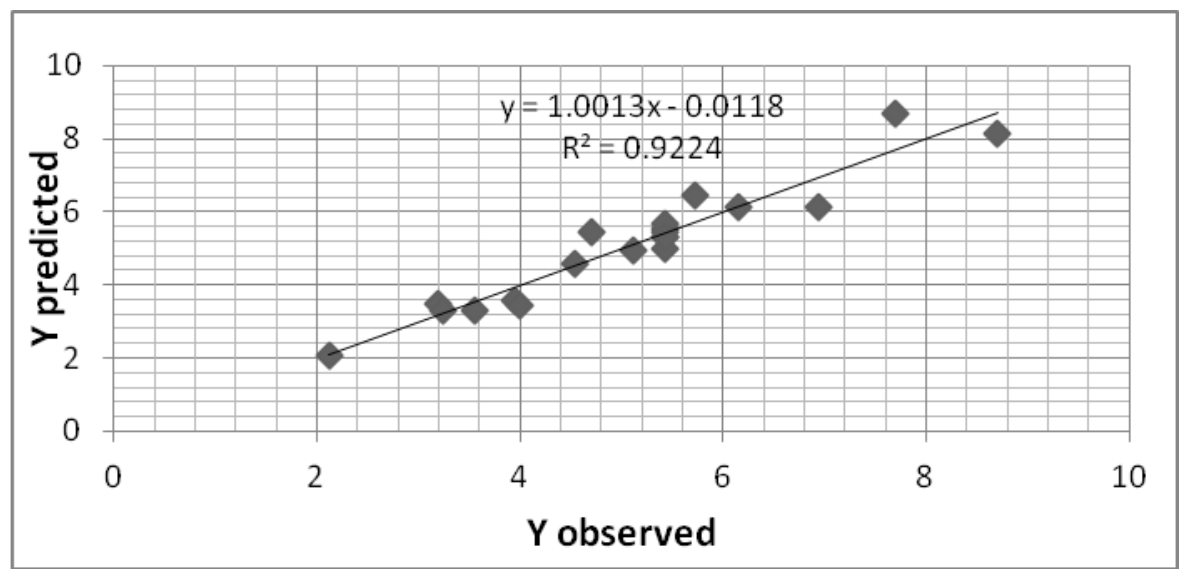

Figure 3: Plot of Observed Response Values versus Predicted Values of Ethanol Yield

The relationship between observed and predicted response values can also be better understood by examining the series of surfaces displayed by the variation of two factors while a third is kept at the optimum level as illustrated in Figures $4-6$. 


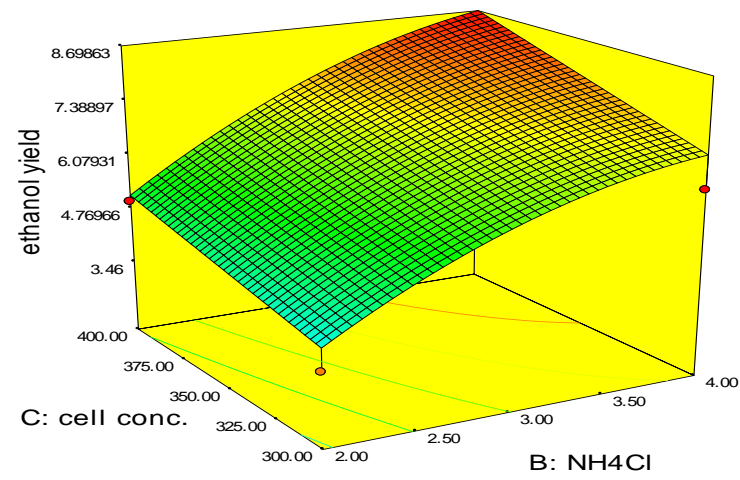

Figure 4: Surface Plot for the Effect Cell Conc. versus $\mathrm{NH}_{4} \mathrm{Cl}$ on Ethanol Yield $\left(\mathrm{B}=\mathrm{x}_{2}, \mathrm{~g} ; \mathrm{C}=\mathrm{x}_{3}, \mathrm{CFU}\right)$

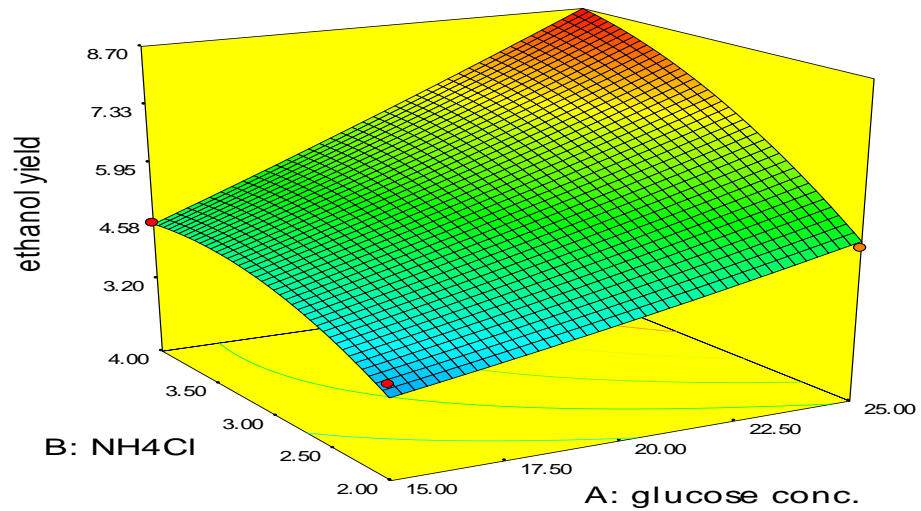

Figure 5: Surface Plot for the Effect $\mathrm{NH}_{4} \mathrm{Cl}$ versus Glucose Conc. on Ethanol Yield $\left(A=x_{1}, g / l ; B=x_{2}\right.$, g)

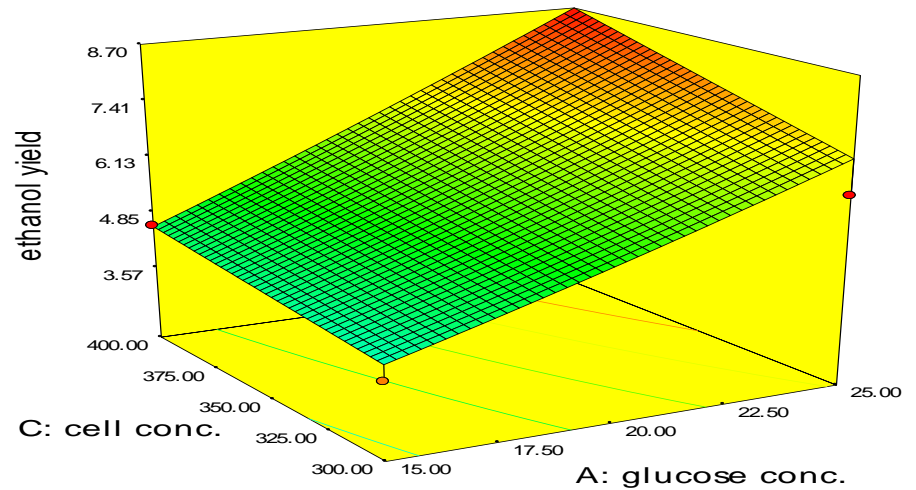

Figure 6: Surface Plot for the Effect Cell Conc. versus Glucose Conc. on Ethanol Yield $\left(A=x_{1}, g / l ; C=\right.$ $\left.x_{3}, \mathrm{CFU}\right)$ 
Based on the response model in equation (7) and the use of the experimental design data, the conversion parameters, $x_{1}, x_{2}$ and $\mathrm{X}_{3}$ obtained at optimum working condition were found to be $24.99 \mathrm{~g} / \mathrm{l} ; 3.99 \mathrm{~g}$ and 399.94 $\mathrm{CFU}\left(\times 10^{6} / \mathrm{ml}\right)$ respectively. This corresponds to an optimum ethanol yield of $8.69 \% \mathrm{v} / \mathrm{v}$. Teerapatr et al.,(2004) in their work on ethanol fermentation of waste from cassava starch plant, reported a maximum ethanol yield of $4.86 \% \mathrm{v} / \mathrm{v}(3.84 \% \mathrm{w} / \mathrm{v})$ after 5 days of fermentation with Saccharomyces cerevisiae, while in a similar work by Nadya et al.,(2012) on the optimization of the condition for ethanol fermentation of pineapple peel extract using response surface method, an optimum ethanol yield of $8.63 \% \mathrm{v} / \mathrm{v}$ was reported.

The results of the analysis of variance (ANOVA) performed on the model using the 'Design Expert 7' software is presented in Tables 3.

Table 3: ANOVA for Response Surface Quadratic Model (Test for Significance)

\begin{tabular}{|l|l|l|l|l|l|}
\hline Source & $\begin{array}{l}\text { Sum } \\
\text { Squares }\end{array}$ & $\begin{array}{l}\text { Degree of } \\
\text { Freedom, df }\end{array}$ & $\begin{array}{l}\text { Mean } \\
\text { Square }\end{array}$ & F Value & -value \\
\hline Model & 46.720799 & 9 & 5.19119989 & 13.1106978 & 0.0002 \\
\hline $\begin{array}{c}\mathrm{X}_{1} \text {-glucose } \\
\text { conc. }\end{array}$ & 20.8227568 & 1 & 20.8227568 & 52.5891658 & $<0.0001$ \\
\hline $\mathrm{X}_{2}$-NH4Cl & 15.6225407 & 1 & 15.6225407 & 39.4556969 & $<0.0001$ \\
\hline $\mathrm{X}_{3}$-cell conc. & 2.55977159 & 1 & 2.55977159 & 6.46486216 & 0.0292 \\
\hline $\mathrm{X}_{1} \mathrm{X}_{2}$ & 2.5200125 & 1 & 2.5200125 & 6.36444811 & 0.0302 \\
\hline $\mathrm{X}_{1} \mathrm{X}_{3}$ & 0.6555125 & 1 & 0.6555125 & 1.65553754 & 0.2272 \\
\hline $\mathrm{X}_{2} \mathrm{X}_{3}$ & 0.2016125 & 1 & 0.2016125 & 0.50918489 & 0.4918 \\
\hline $\mathrm{X}_{1}{ }^{2}$ & 0.07507944 & 1 & 0.07507944 & 0.1896178 & 0.6725 \\
\hline $\mathrm{X}_{2}{ }^{2}$ & 4.08227771 & 1 & 4.08227771 & 10.3100459 & 0.0093 \\
\hline $\mathrm{X}_{3}{ }^{2}$ & 0.00018329 & 1 & 0.00018329 & 0.00046292 & 0.9833 \\
\hline Residual & 3.95951457 & 10 & 0.39595146 & & \\
\hline Lack of Fit & 3.68431094 & 5 & 0.73686219 & 13.3875812 & 0.0064 \\
\hline Pure Error & 0.27520363 & 5 & 0.05504073 & & \\
\hline Cor Total & 50.6803135 & 19 & & & \\
\hline
\end{tabular}

The test of significance of the response model (equation (7)) indicates that glucose concentration $\left(\mathrm{x}_{1}\right)$ has a significant effect $(P<0.0001)$ on the ethanol yield and it has the largest coefficient followed by $\mathrm{NH}_{4} \mathrm{Cl}$ concentration $\left(\mathrm{x}_{2}\right)$ and cell concentration $\left(\mathrm{x}_{3}\right)$. $\mathrm{P}$ value of less than 0.0500 for any term in the model indicates that the term is significant, while a $P$ - value greater than 0.1000 indicates that the term is not significant. Therefore, $x_{1}, x_{2}, x_{3}, x_{1} x_{2}$ and $\mathrm{x}_{2}{ }^{2}$ are highly significant terms in the model. The model did not show lack of fit $(P$-value $=$
$0.0064)$, while the F-value of 13.11 indicates that the model is accurate and that there is only a $0.02 \%$ chance that a 'model F-value' this large could occur due to noise.

Model terms that are not statistically significant do not contribute significantly to the model output, and can be deleted from the model equation without loss of accuracy, thereby simplifying the model. Consequently, the model in equation (7) may be more appropriately represented as shown in equation (8):

$$
\begin{aligned}
\text { Yield }(Y)=5.42+ & 1.23 x_{1}+1.07 x_{2}+0.43 x_{3}+0.56 x_{1} x_{2}+ \\
& 0.29 x_{1} x_{3}-0.53 x_{2}^{2}
\end{aligned}
$$

Table 4 gives the results of the test for adequacy of the modified model in equation (8). As may be seen in Table 4, the coefficient of determination $\left(R^{2}\right)$ remained at a value of 0.92 , while the "pred R-Squared" of 0.4409 is not as close to the "Adj R- Squared" of 0.8516 as might 
be expected. The "Adeq precision" measures the signal to noise ratio, for which a ratio greater than
4 is desirable. Thus the ratio of 14.8083 obtained in Table 4 indicates an adequate signal.

Table 4: ANOVA for Response Surface Quadratic Model (Test for Adequacy)

\begin{tabular}{|l|l|l|l|l|}
\hline Std. Dev. & 0.62924674 & & R-Squared & 0.92187273 \\
\hline Mean & 5.10395521 & & $\begin{array}{l}\text { Adj R- } \\
\text { Squared }\end{array}$ & 0.85155819 \\
\hline C.V. \% & 12.3286101 & & $\begin{array}{l}\text { Pred R- } \\
\text { Squared }\end{array}$ & 0.44090665 \\
\hline PRESS & 28.3350263 & & $\begin{array}{l}\text { Adeq } \\
\text { Precision }\end{array}$ & 14.8083024 \\
\hline
\end{tabular}

\section{CONCLUSION}

The ethanolic fermentation of cassava waste water was investigated. The parameters influencing the ethanol fermentation process namely, the glucose concentration, nutrient level, and the cell concentration were optimised using rotatable central composite design (CCD) and response surface methodology (RSM). The optimum values of glucose concentration, nutrient level and cell concentration were found to be $24.991 \mathrm{~g} / \mathrm{l}, 3.991 \mathrm{~g}$ and $399.4 \mathrm{CFU}\left(\times 10^{6} / \mathrm{ml}\right)$ respectively. The maximum ethanol yield of 8.69 $\% \mathrm{v} / \mathrm{v}$ of ethanol in the broth was obtained at the optimum condition. ANOVA and other statistical tools such as coefficient of determination $\left(R^{2}\right)$ and $P$-value were used to establish the accuracy of the model. The regression model was found to represent closely the experimental ethanol yield, and could be used to predict the process.

\section{REFERENCES}

Alegre, R. M., Rigo, M and Joekes, I., 2003. Ethanol Fermentation of Diluted Molasses Medium by Saccharomyces cerevisiae Immobilized on Chrysotile. Brazilian Archives of Biology and Technology 46, (4): 751-757.

Amenaghawon, N. A., 2010. Evaluation of Ethanol Stripping from Fermenters. M. Sc. Thesis, Imperial College London, UK.

Amutha, R and Gunasekaran, P., 2001. Production of Ethanol from Liquefied Cassava Starch using Co-immobolized cells of Zymomonas mobilis and Saccharomyces diataticus. Journal of Bioscience and Bioengineering 92, (6): 560-564.
DaCosta, A. C and Filho, R. M., 2004. Evaluation of Optimization Techniques for an Extractive Alcohol Fermentation Process. Applied Biochemistry and Biotechnology 113-116: 485-496.

Egemba, K. C and Babatunde, A. A., 2008. Fuel Alcohol Production: Using Cassava as a Feedstock in Nigeria. International Research Journal in Engineering, Science \& Technology 5, (1): 31-38.

Ibeto, C. N., Ofuefule, A. U and Agbo, K. E., 2011. A Global Overview of Biomass Potentials for Bioethanol Production: A Renewable Alternative Fuel. Trends in Applied Sciences Research 6, (5): 410-425.

Kongkiattikajorn, J., Rodmui, A and Dandusitapun, Y., 2007. Effect of Agitation Rate on Batch Fermentation of Mixture culture of Yeasts During Ethanol Production from Mixed Glucose and Xylose. Thai J. Biotechnol. 8, (1): 1-4.

Kuiper, L., Ekmekci, B., Hamelinck, C., Hettinga, W., Meyer, S and Koop, K., 2007. Bioethanol from cassava. A report presented at the Upstream Committee Annual Meeting. Accessed June 9, 2010 from http://www.ecofys.com

Mandenius, C. F and Brundin, A., 2008. Bioprocess Optimization using Design of Experiments Methodology. Biotechnol. Prog. (24): 1191-1203.

Manikandan, $\mathrm{K}$ and Viruthagiri, T., 2010. Kinetic and Optimization studies on Ethanol Production from Corn Flour. International Journal of chemical and Biomolecular Engineering 3, (2): 65-69. 
Nadya, H., Zainal, S., Atikah, $\mathrm{O}$ and Tengku

Elida, T. Z. M., 2012. Optimization of Ethanol Fermentation from Pineapple Peel Extract Using Response Surface Methodology (RSM). World Academy of Science, Engineering and Technology (72): 641-647.

Nzelibe, H. C and Okafoagu, C. U., 2007. Optimization of Ethanol Production from Garcinia Kola pulp Agrowaste. African journal of Biotechnology 6, (17): 20332037.

Peter, E. A., 2009. Alcohol, Calorie, and Attenuation Level of Beer. Accessed January 26, 2011 from http://www.hbd.org/brewery/library/AIClbi nger.html.

Popa, O., Babeanu, N., Vamanu, A and Vamanu, E., 2007. Utilization of the Response Surface Methodology for the Optimization of Cultivation Medium and Growth Parameters in the Cultivation of the Yeast Strain S. cerevisiae 3.20 on Ethanol. African Journal of Biotechnology 6, (23): 2700-2707.

Prescott and Dunn's., 2004. Industrial Microbiology. $4^{\text {th }}$ Edition, CBS. Gerrald Reed, New Delhi - India.

Rahman, S. H. A., Choudhury, J. P., Ahmad, A. L and Kamaruddin, A. H., 2007. Optimization Studies on Acid Hydrolysis of Oil Palm Empty Fruit Bunch Fibre for Production of Xylose. Bioresource Technology (98): 554-559.

Ranola, R. F. (Jr)., Demafelis, R. B., DelRosario, E and Bataller, B. G., 2009. Enhancing the Viability of Cassava Feedstock for Bioethanol in the Philippines. J. ISSAAS 15, (2): 147-158.

Ratnam, B. V. V., Rao, S. S., Rao, D. M., Rao, M. $\mathrm{N}$ and Ayyanna, C., 2005. Optimization of Medium Constituents and Fermentation Conditions for the Production of Ethanol from Palmyra jaggery using Response Surface Methodology. World Journal of Microbiology \& Biotechnology (21): 399404.
Scott, S., 2006. Measurement of Cell Concentration in Suspension by Optical Density. Accessed September 13, 2010. from http://www.linkedin. Com/in/scttvwsutton

Stat-Ease Inc., 2003. Design-Expert ${ }^{\circledR}$ 7- Software for Design of Experiments. 2021 East Hennepin Avenue, Minneapolis, MN 55413.

Taherzadeh, M. J and Karimi, K., 2008. Pretreatment of Lignocellulosic Wastes to Improve Ethanol and Biogas Production: A Review. Int. J. Mol. Sci. (9): 1621-1651.

Teerapatr, S., Cholada, S., Bongotrat, $\mathrm{P}$ and Wichen, K., 2004. Utilization of Waste from Cassava Starch Plant for Ethanol Production. The Joint International Conference on Sustainable Energy and Environment, Hua Hin, Thailand 3- 042: 344-349.

Tsoutsas, T., Kanellaki, M., Psarianos, C., Kalliafas, A and Koutinas, A. A., 1990. Kissiris: A Mineral Support for the Promotion of Ethanol Fermentation by Saccharomyces cerevisiae. J. Ferment. Bioeng. 69, (2): 93-97.

Vlyssides, A., Baramponti, E. M., Mai, S., Stamatoglou, E and Rigaki, K., 2009. Hydrolysis of Starch using Fenton's Reagent as a Key for Waste Integrated Management in a Potato Processing Industry. School of Chemical Engineering, National Technical University of Athens.

Wrolstad, R. E., Decker, E. A., Schwartz, S. J and Sporns, P., 2007. Hand Book of Analytical Chemistry. Elsevier India. 